\title{
Transient and Persistent Expression of NT-3/HDNF mRNA in the Rat Brain during Postnatal Development
}

\author{
Wilma J. Friedman, Patrik Ernfors, and Håkan Persson \\ Department of Medical Chemistry, Laboratory of Molecular Neurobiology, Karolinska Institute, S-10401 Stockholm, \\ Sweden
}

\begin{abstract}
Neurotrophin-3 (NT-3) is closely related to two known neurotrophic agents, NGF and brain-derived neurotrophic factor (BDNF), and acts upon overlapping, yet distinct, populations of peripheral ganglia. NT-3 mRNA expression in the adult rat brain is largely confined to the hippocampus. In this study, we have used in situ hybridization to examine expression of this novel neurotrophic factor during postnatal development. The striking observation was made that NT-3 mRNA was transiently expressed at high levels in the cingulate cortex during the first 2 weeks of age. In the hippocampus, the adult pattern of expression, in the CA2, medial CA1, and granule layer of the dentate gyrus, was detected at all ages examined. However, there were two major differences in NT3 mRNA expression in the developing hippocampus: Labeled cells were detected in the hilar region of the dentate gyrus at postnatal day 1 (P1) and 1 week that were absent by 2 weeks of age. Further, the caudal hippocampus, which has a lower intensity of labeling than the rostral region in the adult, was devoid of NT-3-expressing cells in the P1 and 1 -week-old rat brain. These data indicate a substantial plasticity in NT-3 mRNA expression and suggest that the spectrum of neurons supported by NT-3 during development is partlally different from that in the mature rat brain.
\end{abstract}

During ontogeny of the nervous system, developing neurons require a variety of epigenetic signals to undergo normal maturation. Such signals may come from numerous different sources: presynaptic input, non-neuronal cells, the hormonal milieu, and the target being contacted. Among these possibilities the role of target-derived neurotrophic factors has been extensively studied, and it has been clearly established that such factors play an important role in neural devclopment (for revicw, see Barde, 1989). Neurons that are overproduced during development are thought to compete for limiting quantities of a neurotrophic factor. Those cells that compete successfully reach maturity, while the others are eliminated during the period of naturally occurring cell death (Oppenheim, 1985; Barde, 1989). The bestcharacterized such factor, NGF, is critical for the survival and

\footnotetext{
Received Sept. 5, 1990; revised Dec. 27, 1990; accepted Jan. 4, 1991.

W.J.F. was supported by a fellowship from the Wenner-Gren Foundation, and P.E. received fellowship support from the Swedish Medical Research Council. Further grant support for this work came from the Swedish Natural Sciences Research Council, Magnus Bergvall's Stiftelse, and Augusta and Petrus Hedlunds Stiftelse.

Correspondence should be addressed to Dr. Wilma J. Friedman, Department of Medical Chemistry, Laboratory of Molecular Neurobiology, Karolinska Institute, Box 60400, S-10401 Stockholm, Sweden.

Copyright (C) 1991 Society for Neuroscience $0270-6474 / 91 / 111577-08 \$ 03.00 / 0$
}

function of sympathetic and neural crest-derived sensory neurons in the periphery (Levi-Montalcini and Angeletti, 1968; Thoenen and Barde, 1980; Levi-Montalcini, 1987), as well as cholinergic, and possibly other, neuronal populations in the brain (for reviews, see Thoenen et al., 1987; Whittemore and Seiger, 1987; Dreyfus, 1989; Ebendal, 1989).

Apart from NGF, indirect evidence for the existence of many other neurotrophic factors has been obtained from numerous in vitro experiments using various tissue extracts (Dohrmann et al., 1986; Tomozowa and Appel, 1986) or cocultures (Prochiantz et al., 1979; Hoffman et al., 1983) to demonstrate support of neuronal development and survival. Thus, it was likely that other neurotrophic factors exist that may support distinct or overlapping populations of cells. The purification of brainderived neurotrophic factor (BDNF; Barde et al., 1982) demonstrated this to be true. BDNF influences survival of peripheral sensory neurons in vitro (Lindsay et al., 1985; Davies et al., 1986) and in vivo (Hofer and Barde, 1988), as well as retinal ganglion cells in vitro (Johnson et al., 1986). The spectrum of BDNF activity overlaps, yet is distinct from, that of NGF (for review, see Barde, 1989). The subsequent isolation of the gene for BDNF (Leibrock et al., 1989) led to the striking observation that the deduced primary structure of BDNF showed strong similarity to NGF, suggesting the possible existence of a gene family of related neurotrophic factors. The homologous sequences were used by several groups to isolate a third member of this neurotrophic factor family, neurotrophin-3 (NT-3; Hohn et al., 1990; Maisonpierre et al., 1990a; Rosenthal et al., 1990), also known as hippocampal-derived neurotrophic factor (HDNF; Ernfors et al., 1990a) and NGF2 (Kaisho et al., 1990).

The three neurotrophic factors influence a partially overlapping range of peripheral ganglia. Thus, in neurite outgrowth assays, NGF stimulates embryonic dorsal root ganglia (DRG) and sympathetic ganglia (SG), BDNF influences DRG and the placode-derived nodose ganglia (NG) but not SG, and NT-3 stimulates DRG and NG and elicits a weak response from SG (Ernfors et al., 1990a; Hohn et al., 1990; Maisonpierre et al., 1990a; Rosenthal et al., 1990). Further, NT-3 was more efficient than NGF at eliciting neurite outgrowth from the Remak ganglion, a nerve trunk in the mesorectum of the chicken embryo (Ernfors et al., 1990a).

The distribution of cells expressing the different factors in the adult rat CNS is unique for each. In the adult rat brain, BDNF mRNA-expressing cells are widely distributed through the cortex, claustrum, and hippocampus, while NT-3 mRNA expression is largely restricted to the hippocampus (Ernfors et al., 1990a,b; Maisonpierre et al., 1990b, Phillips et al., 1990; Wet- 
more et al., 1990). Within the hippocampus, NGF is expressed primarily in neurons scattered throughout the pyramidal layer and stratum oriens, as well as the hilar region of the dentate gyrus (Ayer LeLievre et al., 1988; Ernfors et al., 1990b). BDNF is most highly expressed in the CA2 and CA 3 regions of the hippocampus as well as in the dentate gyrus and hilus, with lower levels in CA1. In contrast, NT-3 mRNA in the adult rat hippocampus is detected only in the medial part of CA1, in CA2, and in the granule layer of the dentate gyrus. Cells in CA3 and the hilar region do not express NT-3 mRNA. Moreover, caudal regions of the hippocampus show decreased labeling for NT-3 mRNA in comparison to rostral regions (Ernfors et al., 1990a,b). Thus, as the three factors have distinct distributions within the hippocampus, they may act upon different afferent populations.

In analysis of total brain mRNA by Northern blot, the developmental peaks of mRNA expression of the three trophic agents differ, with NT-3 reaching maximal levels at earlier stages than NGF and BDNF (Ernfors et al., 1990a). This suggests a precise chronological regulation to meet the requirements of specific populations of developing neurons. These developmental differences may reflect the requirements of distinct neuronal groups for a specific trophic agent at various stages of ontogeny or, alternatively, that the same neuronal population may depend upon the presence of different combinations of factors at specific times (Black, 1986). In the present study, we have used in situ hybridization to examine the distribution of NT-3 mRNA-expressing cells in the rat brain during postnatal development. Our results show that NT-3 mRNA is transiently expressed at high levels in developing neurons of the cingulate cortex. Further, differences in the pattern of NT-3 mRNA-expressing neurons were seen in the developing hippocampus. Thus, our results are consistent with the notion that NT-3 supports the development of neurons that are, at least partially, different from the ones sensitive to the factor in the adult brain.

\section{Materials and Methods}

In situ hybridization. Coronal sections $(14 \mu \mathrm{m})$ from fresh-frozen SpragueDawley rat brains of different ages were cut at $-20^{\circ} \mathrm{C}$ on a cryostat (Leitz, Germany). Three brains from each age were analyzed. Sections were thaw mounted onto slides pretreated with poly-L-lysine $(50 \mu \mathrm{g} / \mathrm{ml})$ and stored at $-20^{\circ} \mathrm{C}$ until brains from all ages had been cut. All sections were then fixed simultaneously in $4 \%$ paraformaldehyde for $30 \mathrm{~min}$ and rinsed twice in PBS. The tissue was dehydrated in a graded series of ethanol washes, including a 5-min incubation in chloroform, and air dried.

To detect NT-3-specific mRNA in the sections, a 50-mer oligonucleotide complementary to nucleotides $667-717$ in the rat NT-3 sequence (Ernfors et al., 1990a) was used. Control probes consisted of a 50-mer oligonucleotide complementary to rat BDNF mRNA corresponding to nucleotides 746-795 in the pig BDNF sequence of Leibrock et al. (1989) and a 50-mer oligonucleotide complementary to rat NGF receptor mRNA (Ernfors et al., 1989). The oligonucleotides were synthesized on an Applied Biosystems 381A DNA synthesizer and labeled at the $3^{\prime}$ end with $\alpha-\left({ }^{35} S\right)$-dATP using terminal deoxyribonucleotidyl transferase (IBI, New Haven, CT) to a specific activity of approximately $10^{9} \mathrm{cpm} / \mu \mathrm{g}$. Probes were purified on a Nensorb column (Du Pont, Wilmington, DE) prior to use.

All sections were hybridized at the same time in a cocktail consisting of $50 \%$ formamide, $4 \times$ SSC $(1 \times$ SSC, $0.15 \mathrm{M} \mathrm{NaCl}, 0.015 \mathrm{M}$ sodium citrate, $\mathrm{pH}, 7.0$ ), $1 \times$ Denhardt's solution, $10 \%$ dextran sulphate, 0.25 $\mathrm{mg} / \mathrm{ml}$ yeast $t$ RNA, $0.5 \mathrm{mg} / \mathrm{ml}$ sheared salmon sperm DNA, $1 \%$ sarcosyl ( $N$-lauryl sarcosine), $0.02 \mathrm{M} \mathrm{Na}_{3} \mathrm{PO}_{4}(\mathrm{pH}, 7.0)$, and $0.05 \mathrm{M}$ dithiothreitol (DTT) with $10^{7} \mathrm{cpm} / \mathrm{ml}$ of probe. The sections were hybridized with $0.4 \mathrm{ml}$ hybridization cocktail per slide at $42^{\circ} \mathrm{C}$ overnight in a humidified chamber and were subsequently washed four times for 20 min each in $1 \times \mathrm{SSC}$ at $55^{\circ} \mathrm{C}$, rinsed in autoclaved water for $2 \mathrm{~min}$, dehydrated in ethanol, and air dried. Slides were exposed to $\beta$-max $x$-ray film (Amersham) for $12 \mathrm{~d}$. They were subsequently dipped in Kodak NTB-3 photo emulsion (diluted $1: 1$ in water), exposed for 5 weeks at $-20^{\circ} \mathrm{C}$, developed with D19 (Kodak), fixed with G333 (Agfa Gevert, Leverkusen, Germany), and counterstained with cresyl violet. Analysis was carried out using a Nikon Microphot microscope.

$R N A$ blots. Hippocampus and cerebral cortex were dissected from rats of different ages and homogenized using a Polytrone in $4 \mathrm{M}$ guanidine isothiocyanate, $0.1 \mathrm{M} \beta$-mercaptoethanol, and $0.025 \mathrm{M}$ sodium citrate $(\mathrm{pH}, 7.0)$. Each homogenate was layered over a 4-ml cushion of $5.7 \mathrm{M} \mathrm{CsCl}$ in $0.025 \mathrm{M}$ sodium citrate $(\mathrm{pH}, 5.5)$ and centrifuged at $18^{\circ} \mathrm{C}$ in a Beckman SW 41 rotor at $35,000 \mathrm{rpm}$ for $16 \mathrm{hr}$. PolyA+ RNA was purified by oligo(dT)-cellulose chromatography (Aviv and Leder, 1972), and the RNA yield was quantified spectrophotometrically before use in blot analysis. PolyA ${ }^{+}$RNA $(20 \mu \mathrm{g})$ from cerebral cortex and hippocampus of each age was subjected to electrophoresis through a $1 \%$ agarose gel containing $0.7 \%$ formaldehyde and transferred to a nitrocellulose filter (Amersham Hybond C-Extra). The filter was then hybridized to a 1020-base-pair Xhol fragment containing a rat NT-3 cDNA insert (Ernfors et al., 1990a) labeled with $\alpha-{ }^{32} \mathrm{P}-\mathrm{dCTP}$ by nick translation to a specific activity of approximately $5 \times 10^{8} \mathrm{cpm} / \mu \mathrm{g}$. The filter was hybridized overnight at $42^{\circ} \mathrm{C}$ in $4 \times \mathrm{SSC}, 40 \%$ formamide, $1 \times$ Denhardt's, and $10 \%$ dextran sulphate. The filters were washed at $54^{\circ} \mathrm{C}$ in $0.1 \times$ SSC and $0.1 \%$ SDS and exposed to Kodak XAR-5 film at $-70^{\circ} \mathrm{C}$.

\section{Results}

NT-3 mRNA is transiently expressed in the developing cingulate cortex

Coronal sections from Sprague-Dawley rat brains at different developmental stages were hybridized to an oligonucleotide probe specific for NT-3 mRNA (Ernfors et al., 1990a). The most striking observation of NT-3 mRNA expression during development was in the cingulate cortex, which was very strongly labeled in the postnatal day 1 (P1) and 1-week-old brains (Fig. 1 $a, b$ ). Very low levels were detectable in the 2 -week-old brain, and labcling was completely absent from the cingulate at 3 weeks of age and thereafter (Figs. 1, 2). The developmental changes in the pattern of NT-3 mRNA expression in the cingulate cortex were equally apparent in both rostral and caudal sections of the developing brain (Figs. 1-3). At the rostral level of the brain shown in Figure 1 , at the closure of the corpus callosum, strong signals were seen in the indusium griseum and taenia tecta at $P 1$ and 1 week, with decreasing but still detectable levels throughout development.

\section{Anterior hippocampus}

At a slightly more caudal level, through the anterior hippocampus, high levels of NT-3 mRNA were detected at all ages in the dentate gyrus (Fig. 2). In the 5-week-old brain, the distribution of NT-3 labeling was the same as in the adult (Ernfors et al., $1990 \mathrm{a}, \mathrm{b})$, with strong signals in the medial part of CAl and in $\mathrm{CA} 2$ (Fig. 2e). The same distributions in CA1 and CA2 were observed at all ages, with a somewhat higher labeling intensity in the 5-week-old brain compared to earlier ages. However, labeled cells in the hilar region of the dentate gyrus were clearly detectable at the two earliest ages examined (Fig. 2a,b) and absent by 2 weeks of age (Fig. $2 c$ ). As controls, adjacent sections were hybridized under the same conditions with an oligonucleotidc probc specific for BDNF mRNA (Fig. $2 f$ ) or NGF receptor mRNA (Fig. $2 g$ ). The NGF receptor probe showed the expected pattern of labeling in the horizontal limb of the diagonal band of Broca and the substantia innominata (Gibbs et al., 1989; Koh et al., 1989) and did not label the hippocampus at all. The BDNF probe, though $58 \%$ homologous with the NT-3 probe, showed a clearly distinct pattern of labeling in the 5-week-old hippocampus (Fig. $2 f$ ), reflecting the distribution of BDNF mRNAexpressing cells observed previously in the adult rat brain (Ern- 

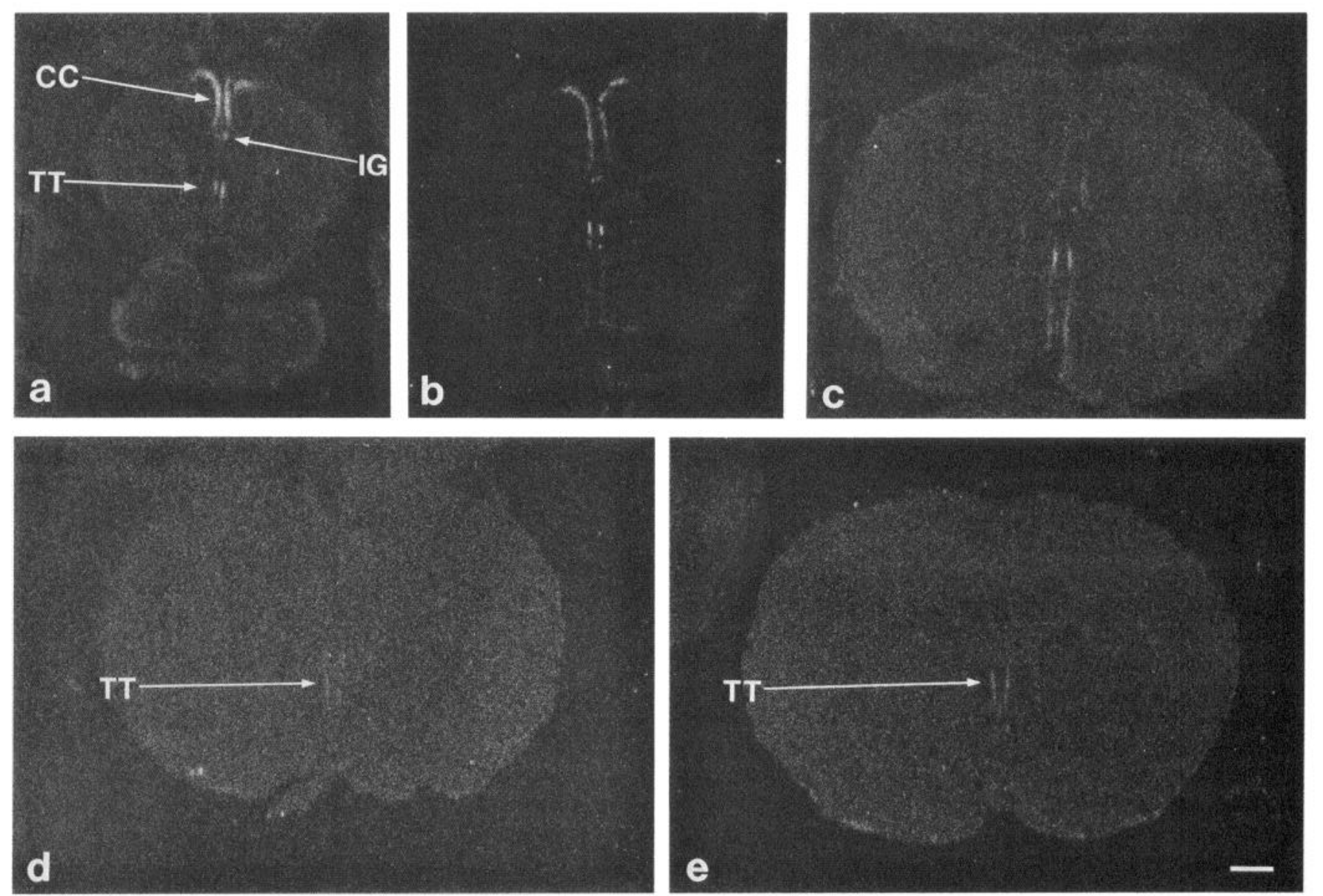

Figure 1. In situ hybridization for NT-3 mRNA in the anterior rat brain of different ages at the level of the closure of the corpus callosum. $a$, $\mathrm{P} 1 ; b, 1$ week; $c, 2$ weeks; $d, 3$ weeks; $e, 5$ weeks. Note that labeling in cingulate cortex $(C C)$ is very low in $c$ and completely absent in $d$ and $e$, while the signal in the taenia tecta $(T T)$ persists, though at lower levels in $d$ and $e . I G$, indusium griseum. Scale bar, $1 \mathrm{~mm}$ for $a-e$.

fors et al., 1990a,b; Hofer et al., 1990; Wetmore et al., 1990). Thus, the labeling observed using the oligonucleotide probe for NT-3 was clearly specific, giving patterns of hybridization distinct from that observed with other probes.

\section{$R N A$ blot analysis of $m R N A$ from the developing cerebral cortex and hippocampus}

Developmental changes in NT-3 mRNA expression in total hippocampus or cerebral cortex were further examined by Northern blot. This analysis revealed a sharp decrease in cortical NT-3 mRNA levels after 1 week of age (Fig. $4 a$ ), reflecting the loss of labeling in the cingulate cortex. The reemergence of a cortical signal in the 5 -week-old and adult brain may reflect labeling in the adult entorhinal cortex seen previously (Ernfors et al., 1990b), because there were no labeled cells present in the 5 -week-old cingulate cortex (Fig. $3 c, d$ ). In the hippocampus, levels of NT-3 mRNA were high at 1 week with slight decreases at 2 and 3 weeks. The amount of NT-3 mRNA was increased slightly at 4 weeks and showed a peak of expression at 5 weeks of age, with a subsequent decline in adult levels (Fig. $4 b$ ).

\section{Posterior hippocampus and cingulate}

It was previously shown in the adult rat that the overall intensity of labeling in the hippocampus decreased in the caudal regions
(Ernfors et al., 1990a,b). In the current study, we discovered that at the youngest ages (P1 and 1 week) labeling was present only in the anterior hippocampus. At more posterior levels, at the level of the temporal lobe, expression of NT-3 mRNA, even in the dentate gyrus, was completely absent (Fig. 5). By 2 weeks of age, the pattern resembled that of the adult, with a lower intensity of labeling in the posterior versus anterior dentate gyrus. Nevertheless, numerous positive cells, with the size and morphology of granular neurons, were seen in the posterior dentate gyrus of 5-week-old animals (Fig. $5 c$ ). In contrast, the intensity of the signal in the cingulate cortex did not diminish in the more caudal regions of the 1 -week-old brain, but remained at high levels (Fig. 3a,b).

\section{Discussion}

The discovery of two additional neurotrophic proteins with structural similarities to NGF has provided an intriguing tool to examine the role of trophic factors in neural development and function. These three factors form a family of neurotrophic factors, and in the adult brain the localization of BDNF and NT-3 mRNA-expressing cells differs from that of NGF, even within the hippocampus, where all three factors are expressed in neurons located in distinct patterns (Ernfors et al., 1990a,b; Phillips et al., 1990). This may suggest that the different agents 


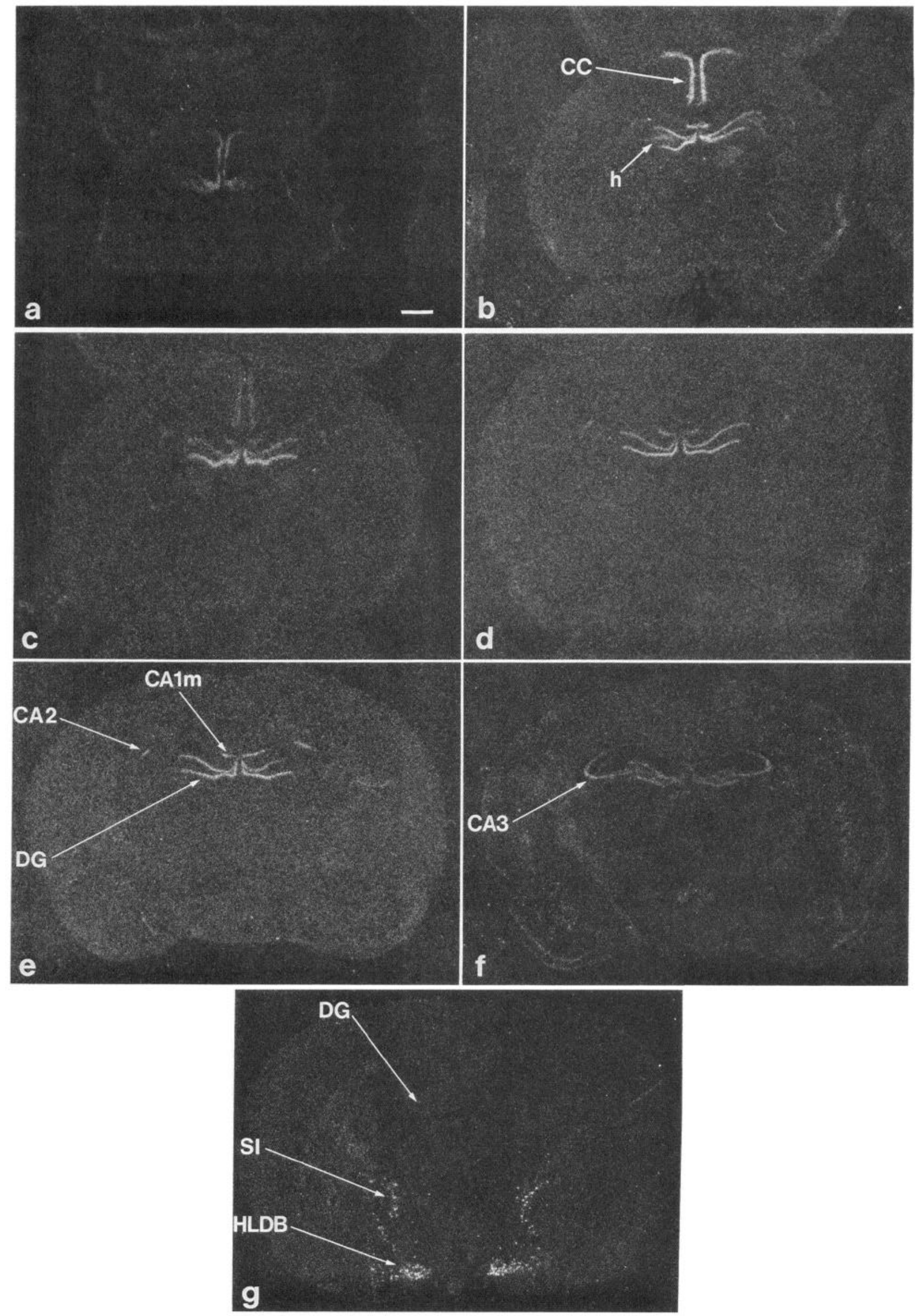



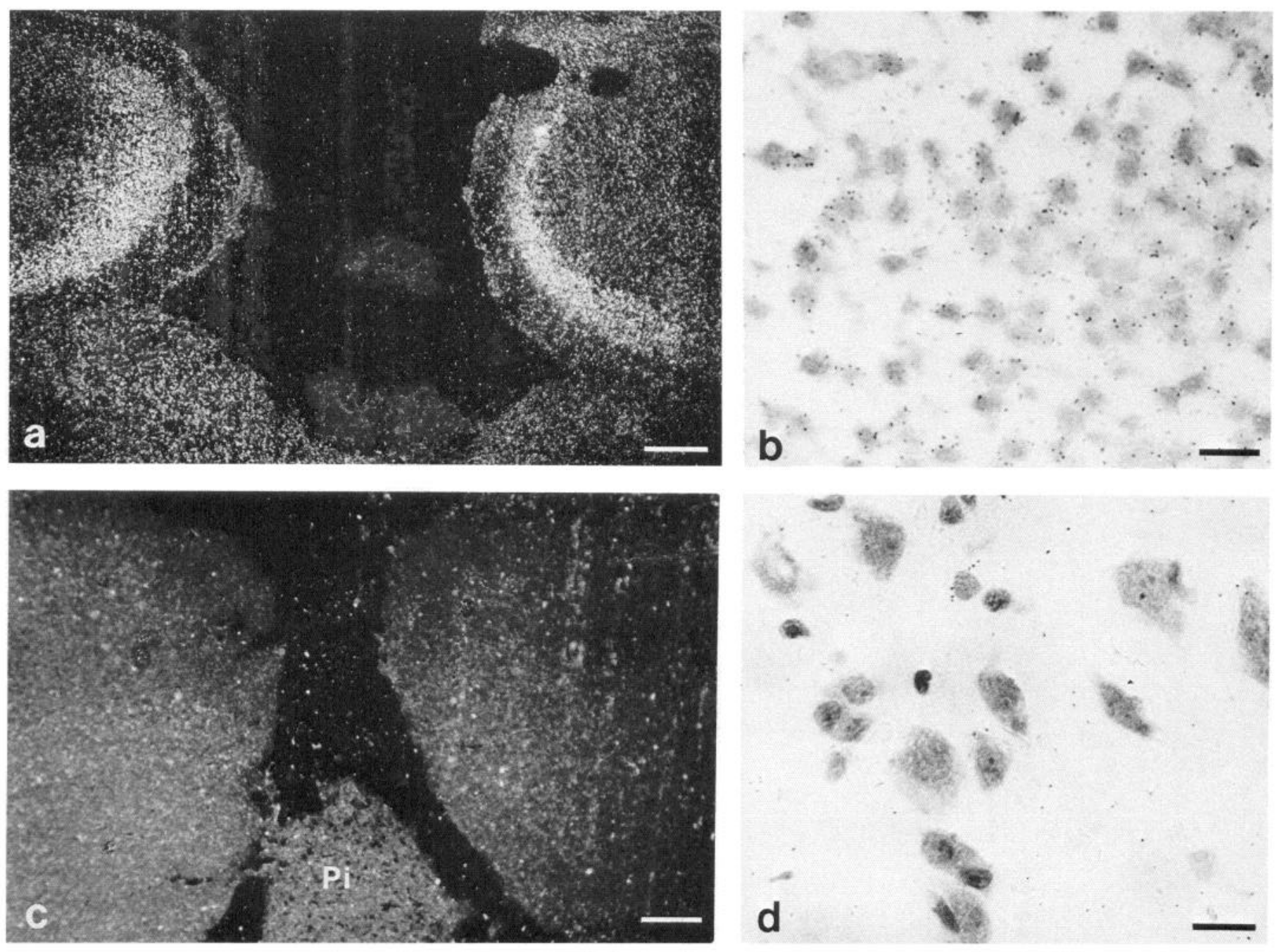

Figure 3. NT-3 mRNA-expressing cells in the caudal cingulate cortex at 1 week $(a, b)$ and 5 weeks $(c, d)$. Dark-field photomicrographs at low magnification clearly show strong signals in the 1-week brain $(a)$ and an absence of labeling at 5 weeks $(c)$. At high magnification, bright-field photomicrographs demonstrate numerous cells at 1 week with a moderate number of grains located over the cytoplasm $(b)$, while no labeled cells were observed in the 5-week brain (d). Pi, pineal gland. Scale bar, $a$ and $c, 200 \mu \mathrm{m} ; b$ and $d, 10 \mu \mathrm{m}$.

act upon distinct afferent populations, though no trophic activity has yet been demonstrated in the CNS for NT-3, and thus far only upon retinal ganglion cells for BDNF (Johnson et al., 1986).

In the present study, we have demonstrated that expression of NT-3 mRNA during postnatal brain development differs in some important ways from that in the adult. The most striking difference was the strong hybridization observed in the cingulate cortex early in development, which was totally absent by 3 weeks of age. The labeling was clearly seen over large cells, presumably neurons, suggesting a mode of action for NT-3 mediated by neuron-neuron interactions. The specificity of the in situ hy- bridization was controlled by hybridization on adjacent sections with similar-length oligonucleotide probes specific for rat BDNF or NGF receptor mRNA, which revealed labeled cells with a distribution in agreement with previous results (Gibbs et al., 1989; Koh et al., 1989; Ernfors et al., 1990a,b; Wetmore et al., 1990), but clearly different from the distribution seen with the NT-3 mRNA-specific probe. Moreover, we have previously shown, using dot blots, that the BDNF and NT-3 oligonucleotide probes do not cross-hybridize under the conditions used in the in situ hybridizations (Ernfors et al., 1990b).

In peripheral adult rat tissues, the levels of both NGF mRNA

Figure 2. Localization of NT-3 mRNA at the level of the anterior hippocampus. $a-e$, sections hybridized with the NT-3 mRNA-specific oligonucleotide probe: $a, \mathrm{P} 1 ; b, 1$ week; $c, 2$ weeks; $d, 3$ weeks; $e, 5$ weeks. Regions indicated in $e$ are labeled at all ages. Note labeling in the hilar region of the dentate gyrus $(h)$ in $b$, which was absent at later times $(c-e)$, and in cingulate cortex $(C C ; a-c)$, not present after 2 weeks of age $(d, e)$. Adjacent sections from 5-week brain are shown as controls hybridized with an oligonucleotide probe specific for BDNF mRNA $(f)$ or a probe specific for the NGF receptor mRNA $(g)$. The BDNF probe showed the strongest hybridization signal in the CA3 region and was weaker in CA1, CA2, and the dentate gyrus $(f)$, in contrast to the pattern of labeling for NT-3 mRNA $(e)$. Note the intense labeling for NT-3 mRNA seen at all ages in the medial dentate gyrus, which is only weakly labeled by the BDNF probe. Hybridization with the NGF receptor probe yielded no signal in the hippocampus $(\mathrm{g})$. CAIm, CA1 medial part; $D G$, dentate gyrus; $S I$, substantia innominata; $H L D B$, horizontal limb of the diagonal band of Broca. Scale bar, $1 \mathrm{~mm}$ for $a-g$. 
a 1wk 2wk 3wk 4wk 5wk Ad

$1.3 \mathrm{~kb}-$

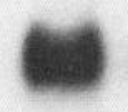

b

$1.3 \mathrm{~kb}-$

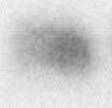

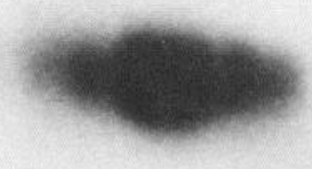

Figure 4. Northern blot analysis for NT-3 mRNA in the developing rat cerebral cortex and hippocampus. PolyA ${ }^{+}$RNA ( $20 \mu \mathrm{g}$ in each lane) from total cortex $(a)$ or hippocampus $(b)$ from the indicated ages was examined. Lanes in $b$ are the same as in $a$. $A d$, adult; $k b$, kilobase; $w k$, week.

and protein correlate with the density of sympathetic innervation (Heumann et al., 1984; Shelton and Reichardt, 1984). Moreover, NGF synthesis in the target field starts with the arrival of the earliest fibers (Davies et al., 1987). If NT-3, like NGF, is a target-derived neurotrophic factor, the expression of NT-3 mRNA in the cingulate cortex during early postnatal development may indicate the presence of transiently NT-3-dependent afferents to this region.

The cingulate cortex is considered to be part of the limbic system and receives a complex array of innervation with a major input via the cingulum from the entorhinal cortex, which in turn receives innervation from multiple cortical regions (Swanson et al., 1987). In addition, the cingulate cortex receives input from a variety of brainstem structures. It is interesting to note that the timing of dopaminergic (DA) innervation of the cingulate cortex closely parallels expression of NT-3 mRNA during development. The first DA afferents originating from the A9 cell group in the substantia nigra reach the cingulate cortex around embryonic day 20 (E20), and the DA innervation progressively increases thereafter with a peak around 1 week after birth. By 3 weeks of age, the DA input appears to be well developed (Verney et al., 1982; Berger and Verney, 1984). A transient expression of preprotachykinin A (PPT-A) mRNA, the common precursor of both substance $\mathrm{P}$ (SP) and neurokinin A (NKA;
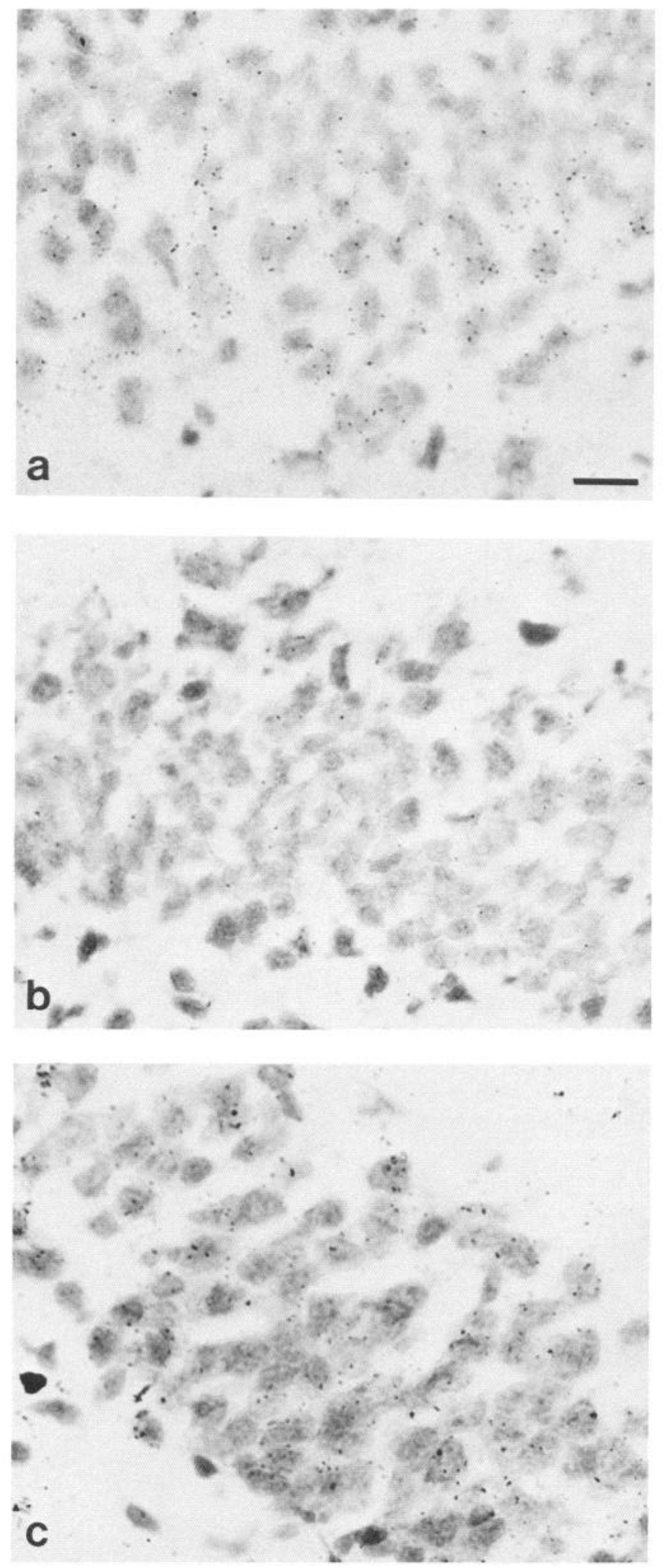

Figure 5. NT-3 mRNA-expressing cells in the developing dentate gyrus. Coronal sections through the anterior dentate gyrus of the 1-week brain clearly show numerous cells in the granule layer that are moderately labeled $(a)$, while sections through the posterior dentate are devoid of labeled cells $(b)$. In the 5-week brain, numerous NT-3 mRNAexpressing cells are detected in the posterior dentate $(c)$. Scale bar, 10 $\mu \mathrm{m}$ for $a-c$. 
Nawa et al., 1984; Krause et al., 1987), has also been observed in the developing cingulate cortex (Brené et al., 1990). At E20 and $\mathrm{P} 4$, approximately $50 \%$ of all cells in cingulate cortex express PPT-A mRNA. Thereafter, the number of PPT-A-positive cells declines to approximately one-third at 1 week and to less than $3 \%$ in the adult. SP has been suggested to exert a neurotrophic effect on noradrenergic neurons from the locus coeruleus (Jonsson and Hallman, 1982). The similar temporal expression of PPT-A and NT-3 mRNA in cells of the developing cingulate cortex suggests the interesting possibility that SP and NT-3 may cooperate to exert a trophic influence on developing catecholamine neurons in this region.

Outside of the adult rat hippocampal formation, NT-3 mRNAexpressing cells have been found only in taenia tecta and indusium griseum [both of which are formed developmentally from the rostral hippocampus (Swanson et al., 1987)] and in one brainstem area, delineated laterally by the locus coeruleus and dorsally by the floor of the fourth ventricle (Ernfors et al., 1990b). Neurons expressing low levels of NT-3 mRNA have also been found in the adult entorhinal cortex. In contrast to the cingulate cortex, but consistent with the adult pattern, expression of NT-3 mRNA was detected in the indusium griseum and taenia tecta at all ages examined. In both structures, more intense labeling was seen at the earliest ages, and the level declined with increasing age, suggesting that NT-3 may play a role both in the early postnatal innervation of these structures and in later maintenance of function.

The distribution of NT-3 mRNA-expressing cells in the hippocampus showed some differences throughout the stages of development examined. In the adult rat, levels of NT-3 mRNA were previously shown to decline towards the more caudal regions of the hippocampus, and no positive cells in the hilar region of the dentate gyrus were detected. This pattern of expression was attained by 2 weeks of age. Prior to that stage, the hilar region was labeled, and no labeled cells were detected at caudal levels in the hippocampus. Thus, it appears that in some regions of the hippocampal formation, such as the hilus, NT-3 may exert a trophic influence predominantly during early postnatal development, playing a less important role in maintaining the adult pattern of innervation in this region. In contrast, the level of NT-3 mRNA in CA1, CA2, and the granule layer of the dentate gyrus increased at later stages of development, as demonstrated by a more intense labeling over these regions at 5 weeks compared to earlier ages. In agreement with this, Northern blots showed a peak in the level of NT-3 mRNA in total hippocampus at 5 weeks of age. This may also be partly due to the presence of NT-3 mRNA-expressing cells in the caudal hippocampus, which were absent at earlier ages. Furthermore, the RNA blots showed somewhat less NT-3 mRNA present at 1 week compared with the adult. Thus, the early peak in NT-3 mRNA expression in total brain seen previously by Northern blots (Ernfors et al., 1990a; Maisonpierre et al., 1990b) was likely due to the high levels in the cingulate cortex at this time.

The transient expression of NT-3 mRNA in cingulate cortex and the hilar region of the dentate gyrus indicates that defined sets of neurons may have specific temporal trophic requirements. The absence of labeling over any cells in these structures by 3 weeks of age indicated either that NT-3 mRNA was no longer expressed in these cells or that the level had declined substantially and was below the detection limit of the in situ hybridization technique. Moreover, the absence of labeling in the posterior hippocampus during early postnatal development, and the subsequent appearance of NT-3 mRNA-expressing cells, suggests that certain afferent neuronal populations may acquire dependence on this trophic factor at later stages of development.

In conclusion, the complex temporal and spatial expression of NT-3 mRNA described in this study suggests that NT-3 may support neuronal innervation in the developing cingulate cortex and hilar region, playing a less important role in adult maintenance. In contrast, in the other areas of the hippocampal formation, such as CA1, CA2, and the dentate gyrus, NT-3 appears to be necessary for supporting afferent innervation both during development and in the adult.

\section{References}

Aviv H, Leder P (1972) Purification of biologically active globin messenger RNA by chromatography over oligothymidylic acid-cellulose. Proc Natl Acad Sci USA 69:1408-1412.

Ayer LeLievre C, Olson L, Ebendal T, Seiger A, Persson H (1988) Expression of the beta-nerve growth factor gene in hippocampal neurons. Science 240:1339-1341.

Barde Y-A (1989) Trophic factors and neuronal survival. Neuron 2: $1525-1534$

Barde Y-A, Edgar D, Thoenen H (1982) Purification of a new neurotrophic factor from mammalian brain. EMBO J 1:549-553.

Berger B, Verney C (1984) Development of the catecholamine innervation in rat neocortex: morphological features. In: Monoamine innervation of cerebral cortex, pp 95-121. New York: Liss.

Black IB (1986) Trophic molecules and evolution of the nervous system. Proc Natl Acad Sci USA 83:8249-8252.

Brené S, Lindefors N, Friedman WJ, Persson H (1990) Perprotachykinin A mRNA expression in the rat brain during development. Dev Brain Res 57:151-162.

Davies AM, Thoenen H, Barde Y-A (1986) The response of chick sensory neurons to brain-derived neurotrophic factor. J Neurosci 6: $1897-1904$

Davies AM, Bandtlow C, Heumann R, Korsching S, Rohrer H, Thoenen H (1987) Timing and site of nerve growth factor synthesis in developing skin in relation to innervation and expression of the receptor. Nature 326:353-358.

Dohrmann U, Edgar D, Sendtner M, Thoenen H (1986) Muscle-derived factors that support survival and promote fiber outgrowth from embryonic chick spinal motor neurons in culture. Dev Biol 118:209221.

Dreyfus CF (1989) Effects of nerve growth factor on cholinergic brain neurons. Trends Pharmacol Sci 10:145-149.

Ebendal T (1989) NGF in CNS: experimental data and clinical implications. Prog Growth Factor Res 1:143-159.

Ernfors P, Henschen A, Olson L, Persson H (1989) Expression of nerve growth factor receptor mRNA is developmentally regulated and increased after axotomy in rat spinal cord motoneurons. Neuron 2:1605-1613.

Ernfors P, Ibáñez CF, Ebendal T, Olson L, Persson H (1990a) Molecular cloning and neurotrophic activities of a protein with structural similarities to $\beta$-nerve growth factor: developmental and topographical expression in the brain. Proc Natl Acad Sci USA 87:5454-5458.

Ernfors P, Wetmore C, Olson L, Persson H (1990b) Identification of cells in rat brain and peripheral tissues expressing mRNA for members of the nerve growth factor family. Neuron 5:511-526.

Gibbs RB, McCabe JT, Buck CR, Chao MV, Pfaff DW (1989) Expression of NGF receptor in the rat forebrain detected with in situ hybridization and immunohistochemistry. Mol Brain Res 6:275-287.

Heumann R, Korsching S, Scott J, Thoenen H (1984) Relationship between levels of nerve growth factor (NGF) and its messenger RNA in sympathetic ganglia and peripheral target tissues. EMBO J 3:31833189.

Hofer MM, Barde Y-A (1988) Brain-derived neurotrophic factor prevents neuronal death in vivo. Nature 331:261-262.

Hofer M, Pagliusi SR, Hohn A, Leibrock J, Barde Y-A (1990) Regional distribution of brain-derived neurotrophic factor mRNA in the adult mouse brain. EMBO J 9:2459-2464.

Hoffman PC, Hemmendinger LM, Kotake C, Heller A (1983) Enhanced dopamine cell survival in reaggregates containing telencephalic target cells. Brain Res 274:275-281. 
Hohn A, Leibrock J, Bailey K, Barde Y-A (1990) Identification and characterization of a novel member of the nerve growth factor/brainderived neurotrophic factor family. Naturc 344:339-341.

Johnson JE, Barde Y-A, Schwab M, Thoenen H (1986) Brain-derived neurotrophic factor supports the survival of cultures rat retinal ganglion cells. J Neurosci 6:3031-3038.

Jonsson G, Hallman H (1982) Substance P counteracts neurotoxin damage on norepinephrine cells in rat brain during ontogeny. Science 215:75-77.

Kaisho Y, Yoshimura K, Nakahama K (1990) Cloning and expression of a cDNA encoding a novel human neurotrophic factor. FEBS Lett 266:187-191

Koh S, Oyler GA, Higgins GA (1989) Localizaton of nerve growth factor receptor messenger RNA and protein in the adult rat brain. Exp Neurol 106:209-221.

Krause JE, Chirgwin JM, Carter JM, Xu ZS, Hershey AD (1987) Three rat preprotachykinin mRNAs encode the neuropeptides substance $P$ and neurokinin A Proc Natl Acad Sci USA 84:881-885.

Leibrock J, Lottspeich F, Hohn A, Hofer M, Hengerer B, Masiakowski P, Thoenen H, Barde Y-A (1989) Molecular cloning and expression of brain-derived neurotrophic factor. Nature 341:149-152.

Levi-Montalcini $\mathbf{R}$ (1987) The nerve growth factor 35 years later. Science 237:1154-1162.

Levi-Montalcini R, Angeletti PU (1968) The nerve growth factor. Physiol Rev 48:534-569.

Lindsay RM, Thoenen H, Barde Y-A (1985) Placode and neural crestderived sensory neurons are responsive at early developmental stages to brain-derived neurotrophic factor. Dev Biol 112:319-328.

Maisonpierre PC, Belluscio L, Squinto S, Ip NY, Furth ME, Lindsay RM, Yancopoulos GD (1990a) Neurotrophin-3: a neurotrophic factor related to NGF and BDNF. Science 247:1446-1451.

Maisonpierre PC, Belluscio L, Friedman B, Alderson RF, Wiegand SJ, Furth ME, Lindsay RM, Yancopoulos GD (1990b) NT-3, BDNF, and NGF in the developing rat nervous system: parallel as well as reciprocal patterns of expression. Neuron 5:501-509.

Nawa H, Kotani H, Nakanishi S (1984) Tissue-specific generation of two preprotachykinin mRNAs from one gene by alternative splicing. Nature 313:729-734.
Oppenheim RW (1985) Naturally occurring cell death during neuronal development. Trends Neurosci 8:487-493.

Phillips HS, Hains JM, Laramce GR, Rosenthal A, Winslow JW (1990) Widespread expression of BDNF but not NT3 by target areas of basal forebrain cholinergic neurons. Science 250:290-294.

Prochiantz A, Di Porzio U, Kato A, Berger B, Glowinski J (1979) In vitro maturation of mesencephalic dopaminergic neurons from mouse embryos is enhanced in presence of their striatal target cells. Proc Natl Acad Sci USA 76:5387-5391.

Rosenthal A, Goeddel DV, Nguyen T, Lewis M, Shih A, Laramee GR, Nikolics K, Winslow JW (1990) Primary structure and biological activity of a novel human neurotrophic factor. Neuron 4:767-773.

Shelton DL, Reichardt LF (1984) Expression of the $\beta$-nerve growth factor gene correlates with the density of sympathetic innervation in effector organs. Proc Natl Acad Sci USA 81:7951-7955.

Swanson LW, Köhler C, Björklund A (1987) The limbic region. I. The septo-hippocampal system. In: I Iandbook of chemical anatomy, Vol 5: Integrated systems of the CNS, part I (Björklund A, Hökfelt T, Swanson LW, eds), pp 125-277. Amsterdam: Elsevier.

Thoenen H, Barde Y-A (1980) Physiology of nerve growth factor. Physiol Rev 60:1284-1335.

Thoenen H, Bandtlow C, Heumann R (1987) The physiological function of nerve growth factor in the central nervous system: comparison with the periphery. Rev Physiol Biochem Pharmacol 109:145-178.

Tomozowa Y, Appel SH (1986) Soluble striatal extracts enhance development of mesencephalic dopaminergic neurons in vitro. Brain Res 399:111-124.

Verney C, Berger B, Adrien J, Vigny A, Gay M (1982) Development of the dopaminergic innervation of the rat cerebral cortex. A light microscopic immunocytochemical study using anti-tyrosine hydroxylase antibodies. Dev Brain Res 5:41-52.

Wetmore C, Ernfors P, Persson H, Olson L (1990) Localization of brain-derived neurotrophic factor mRNA to neurons in the brain by in situ hybridization. Exp Neurol 109:141-152.

Whittemore SR, Seiger A (1987) The expression, localization and functional significance of beta-nerve growth factor in the central nervous system. Brain Res 434:439-464. 